\title{
Pterygoid process fracture during dental extraction - an unusual complication
}

\author{
Gustavo Almeida Souza ${ }^{\mathrm{a}}$, Zarina Tatia Santos ${ }^{\mathrm{a}}$, Alexander Tadeu Sverzut ${ }^{\mathrm{b}}$,

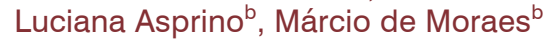

\begin{abstract}
INTRODUCTION: The extraction of the upper third molar is a simple and common procedure in Oral and Maxillofacial Surgery daily practice. Infection, facial swelling, trismus, wound dehiscence, root fracture, oroantral fistula, iatrogenic displacement, fracture of the maxillary tuberosity are some of the complications that can occur during third molar extraction.

CASE DESCRIPTION: In this article, an unusual fracture of the pterygoid process during upper third molar extraction and a minimally invasive technique for treatment are described.

CONCLUSION: It is important to recognize the fracture and not remove the fragment before a complementary image exam, it will guide the type of treatment that should be use.
\end{abstract}

Keywords: minor surgical procedures; intraoperative complications; third molar.

\section{Fratura de processo pterigóide durante extracção dental - uma complicação incomum}

\section{RESUMO}

INTRODUÇÃO: A extração do terceiro molar superior é um procedimento simples e comum na prática diária da cirurgia buco-maxilo-facial. Infecção, inchaço facial, trismo, deiscência de feridas, fratura de raiz, fístula oroantral, deslocamento iatrogênico, fratura da tuberosidade maxilar são algumas das complicações que podem ocorrer durante a extração do terceiro molar.

DESCRIÇÃO DO CASO: Neste artigo, Descreve-se uma fratura incomum do processo pterigóide ocorrida durante a extração do terceiro molar superior e uma técnica minimamente invasiva para o tratamento.

CONCLUSÃO: É importante reconhecer a fratura e não remover o fragmento antes de um exame de imagem complementar, ele irá orientar o tipo de tratamento que deve ser usado.

Palavras-chave: procedimentos cirúrgicos menores; complicações intraoperatórias; terceiro molar. a PhD Student, Department of Oral Diagnosis Oral and Maxillofacial Surgery Division, Piracicaba Dental School, Universidade Estadual de Campinas, Piracicaba, SP, Brazil

${ }^{b}$ Professor of Oral and Maxillofacial Surgery, Piracicaba Dental School, Universidade Estadual de Campinas, Piracicaba, SP, Brazil 


\section{INTRODUCTION}

The removal of the upper third molar is a simple and common procedure in Oral and Maxillofacial Surgery daily practice [1]. However, complications may occur, with a rate ranging from $4.6 \%$ to $18.9 \%$, and there is a relative paucity of studies devoted to assess demographic (i.e. age and gender), anatomic and operative factors associated with third molar extraction difficult [2-4].

Infection, facial swelling, trismus, wound dehiscence, root fracture, oroantral communication, iatrogenic displacement, fracture of the maxillary tuberosity are some of the complications that can occur during removal of third molar [2-8]. The fracture of a large portion of the maxillary tuberosity area is a particular concern situation, which can result in torrential hemorrhage due to proximity of significant blood vessels [9]. The oroantral communication seems to be the most common complication related, whereas large fractures of the maxillary tuberosity, mainly involving the pterygoid process, are extremely rare $[4,6,10]$.

This article aims to describe a case of pterygoid process fracture during the removal of upper third molar and a minimally invasive treatment technique.

\section{CASE DESCRIPTION}

A healthy 38-year-old man was referred to the Oral and Maxillofacial Surgery Division of Piracicaba Dental School, Universidade Estadual de Campinas, Piracicaba-SP, by his general dentist after an attempt to removal his upper right third molar. The patient related that the procedure was interrupted by the dentist, because of the pain and the bleed that was occurring. He reported also that the procedure was delayed and that the dentist used too much force and handpieces.

During our initial clinical examination, there was no bleeding at surgery site. Under local anesthesia, was verified that the tooth and bone fragment attached to it were with mobility, but were also connected to a deep, strong and elastic structure. In addition, the patient complained about nausea when the fragment was moved.

The procedure was interrupted and a Computed Tomography Scan (CT scan) was performed, showing that the attached bone fragment was larger than imagined comprising not only the tuberosity, but also the pterygoid process (Fig. 1).

The patient was informed about the need of general anesthesia for any other intervention to solve his problem and he accepted it. The surgical exploration showed that the bone fragment had a strong muscle attached to it, which could not be released by sub-periosteal dissection, because of uncontrollable deep bleeding and limited access, so a fissure bur (702) in a straight handpiece was used to do the superior horizontal cut and divide the block fractured in two parts, the lower one with the tooth and the upper one with the pterygoid process (Fig. 2).

The fractured pterygoid process was left in place and then it was retracted into the infratemporal fossa by the muscle.
An oroantral communication with the size of a fingertip was felt in the posterior-inferior wall of the maxillary sinus, to solve this a Bichat's fat pad pedicled graft and a resorbable horizontal mattress sutures were used to close it primarily.

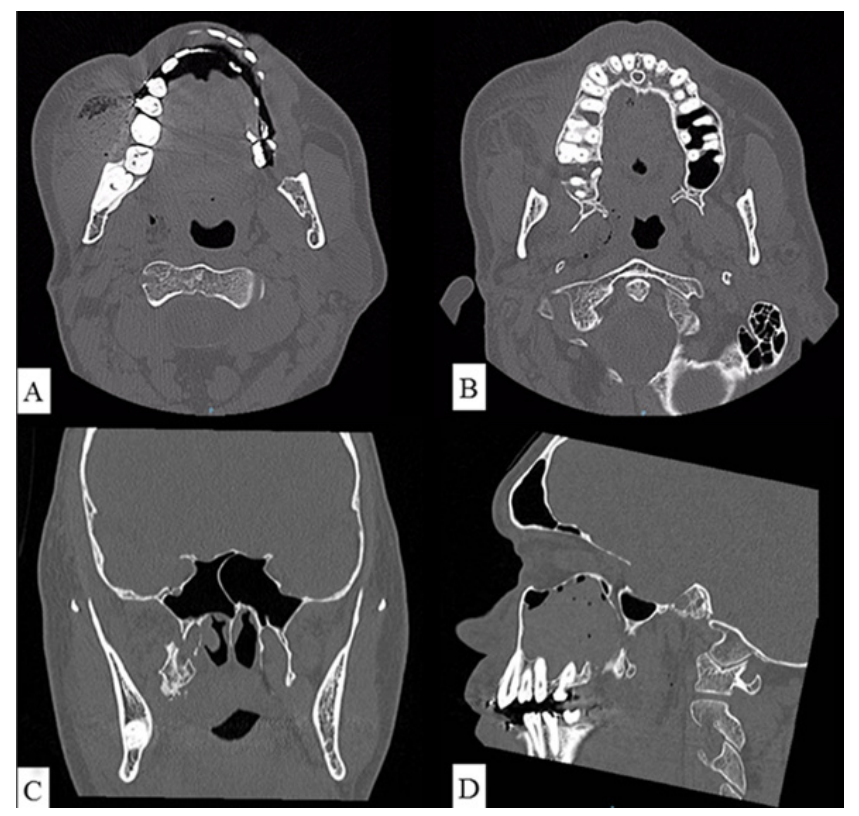

Figure 1. A - Axial view showing the presence of generalized edema and subcutaneous emphysema in right buccal region. B - Axial view showing the tooth attached to a large maxillary bone fragment and pterygoid process, with posterior displacement. C - Coronal view showing a high pterygoid process fracture. D - Sagital view showing the presence of hematossinus and an oroantral communication.

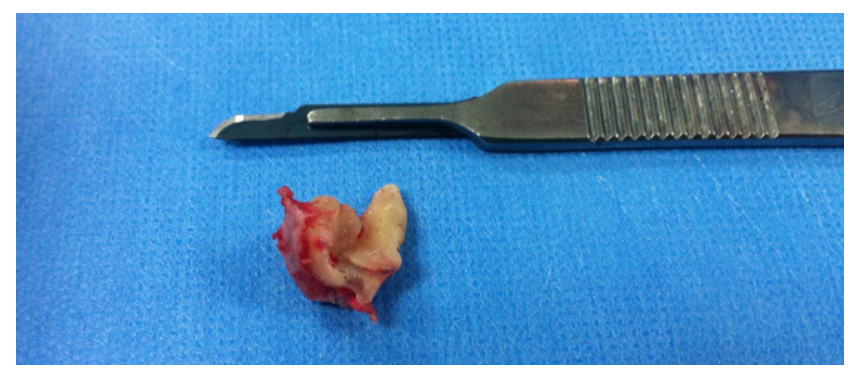

Figure 2. Remnant of the tooth and attached bone fragment.

During the postoperative period, a seven day course of Amoxicillin 500 milligrams every 8 hours and a Chlorhexidine Gluconate $0,12 \%$ mouthwash (twice per day) were prescribed together with adequate pain killers (paracetamol 500 milligrams every 6 hours). In addition, as a usual post extraction instruction, the patient was advised to avoid blowing his nose for two weeks to prevent the development of an oroantral fistula. The patient had an uneventful recovery and optimal opening of the mouth.

Six months after surgery, the patient remained asymptomatic and the postoperative tomography showed absence of infectious signs and total healing of the surgical area (Fig. 3). After confirmation of clinical improvement, the patient was discharged. 


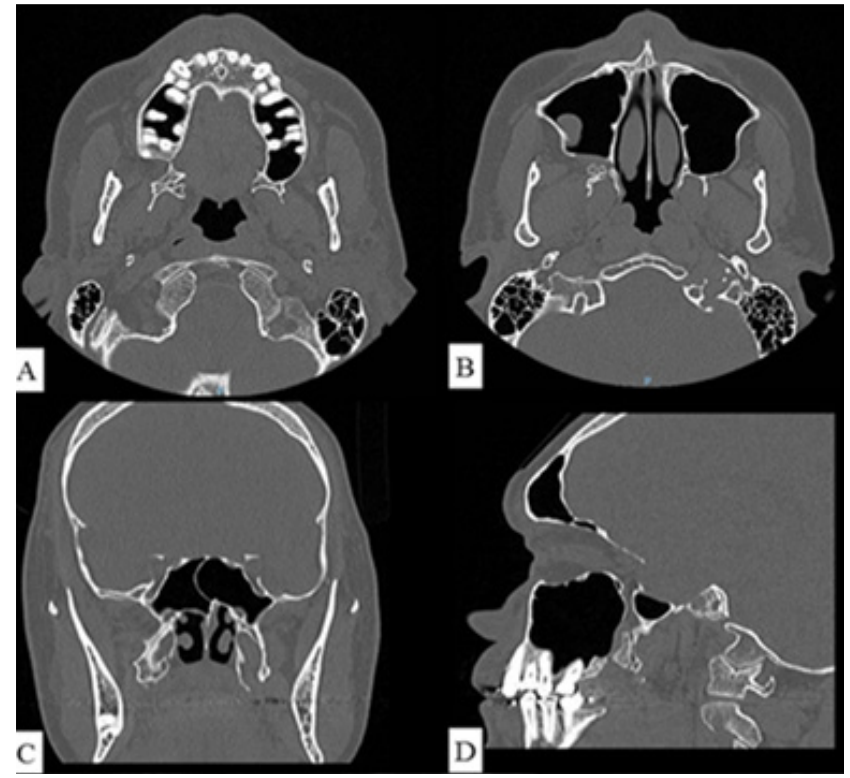

Figure 3. A - Axial view showing bone defect caused by exodontia and bone bridge between fractured fragment and maxillary bone. B - Axial view showing an antral pseudocyst and the absence of complicationrelated pathologies. $\mathbf{C}$ - Coronal view showing bone healing of the pterygoid process fracture. D - Sagital view showing the absence of the hematossinus or other pathologies.

\section{DISCUSSION}

The fracture of maxillary tuberosity is associated with: maxillary sinus enlargement, tooth fusion, ankyloses and roots widely divergent [6]. Patients older than 25 years are $46 \%$ more susceptible to develop complications, because of bone properties alteration including the bone density $[4,11]$. The case described in this paper is the combination of all these factors.

Another factor mentioned in the literature is the malpractice [10]. It can be assumed that a factor associated with this complication was the excessive use of force and the inappropriate use of handpieces, referred by the patient.

A type of treatment for maxillary tuberosity fractures is to stabilize the mobile part of the bone with rigid fixation techniques for 4-6 weeks [10], but this was not our conduct because the tooth involved had carious lesion and at the time of our intervention a portion of the crown had already been removed. When this complication is recognized by the dentist the maxillary tuberosity should not be removed and the patient must be referred to a specialized health center $[6,9]$.

The patient was referred to our division because of the inability of the dentist to remove the tooth and bone fragment, in addition to the presence of pain and brisk bleed. We emphasize the importance of recognize the fracture and not remove the fragment before a complementary image exam, it will guide the type of treatment that should be use.

Fragile vessels in the region of the posterior maxilla and tuberosity, such as branches of the maxillary artery (descending palatine artery, posterior superior alveolar artery, sphenopalatine artery) and pterygoid plexus, are easily ruptured when bone is fractured and separated from periosteum. This can result in torrential bleeding and a lifethreatening situation $[6,9,12]$. In this case, we decided to keep the portion of the fragment with the pterygoid process precisely because the presence of these surrounding structures.

Unlike our decision, some authors [6] discussed a similar case and they decided to free the muscles with surgical scissors. In our opinion, remove the bone portion and maintain the most superior fragment was a less invasive way to solve this complication, since the area of greatest risk is not dissected. But the fragment maintained should be adhered to the periosteum, this can avoid the risk of necrosis during postoperative period and therefore infection.

Fracture of pterygoid process is rare, only one case is reported in literature [6]. This is the first case on our division in 30 years which has a volume of thousand surgery of third molar extraction per year. We conclude that the employed technique used in this case was less invasive and safe.

\section{REFERENCES}

1. Gómez-Oliveira G, Arribas-García I, Alvarez-Flores M, Gregoire-Ferriol J, Martínez-Gimeno C. Delayed removal of a maxillary third molar from the infratemporal fossa. Med Oral Patol Oral Cir Bucal. 2010;15(3):509-11. https://doi.org/10.4317/medoral.15.e509

2. Susarla SM, Dodson TB. Risk factors for third molar extraction difficulty. J Oral Maxillofac Surg. 2004;62:1363-71. https://doi.org/10.1016/j. joms.2004.05.214

3. Barbosa-Rebellato N-L, Thomé A-C, Costa-Maciel C, Oliveira J, Scariot R. Factors associated with complications of removal of third molars: A transversal study. Med Oral Patol Oral Cir Bucal. 2011;16(3):376-80. https://doi.org/10.4317/medoral.16.e376

4. Pourmand PP, Sigron GR, Stadlinger B, Locher MC. The most common complications after wisdom-tooth removal: part 2: a retrospective study of 1562 cases in the maxilla. Swiss Dent J. 2014;124(10):1047-51.

5. Bui CH, Seldin EB, Dodson TB. Types, Frequencies, and Risk Factors for Complications after Third Molar Extraction. J Oral Maxillofac Surg. 2003:61(12):1379-89. https://doi.org/10.1016/j.joms.2003.04.001

6. Shah N, Bridgman JB. An extraction complicated by lateral and medial pterygoid tethering of fractured maxillary tuberosity. $\mathrm{Br}$ Dent $\mathrm{J}$ [Internet]. 2005;198(9):543-4. Available from: <http://www.ncbi.nlm. nih.gov/pubmed/15895047 > . https://doi.org/10.1038/sj.bdj.4812301

7. Sverzut CE, Trivelato AE, Lopes LM de F, Ferraz EP, Sverzut AT Accidental Displacement of Impacted Maxillary Third Molar: A Case Report. Braz Dent J. 2005;16(2):167-70. https://doi.org/10.1590/ S0103-64402005000200015

8. Anand R, Patil PM. Accidental displacement of third molars; report of three cases, review of literature and treatment recommendations. Oral Surg. 2013;6:2-8. https://doi.org/10.1111/ors.12013

9. Bertram AR, Rao ACA, Akbiyik KM, Haddad S, Zoud K. Maxillary tuberosity fracture: A life-threatening haemorrhage following simple exodontia. Aust Dent J. 2011;56:212-5. https://doi.org/10.1111/j.18347819.2011.01326.x

10. Polat HB, Ay S, Kara MI. Maxillary Tuberosity Fracture Associated with First Molar Extraction: A Case Report. Eur J Dent. 2007;1:256-9.

11. Renton T, Smeeton N, McGurk M. Factors predictive of difficulty of mandibular third molar surgery. Br Dent J [Internet]. 2001;190(11): 607-10. Available from: <http://www.ncbi.nlm.nih.gov/pubmed/ 11441899 >. https://doi.org/10.1038/sj.bdj.4801052a

12. Thirumurugan K, Munzanoor RR, Prasad GA, Sankar K. Maxillary tuberosity fracture and subconjunctival hemorrhage following extraction of maxillary third molar. J Nat Sci Biol Med [Internet]. 2013;4(1):242-5. Available from: <http://www.pubmedcentral.nih.gov/articlerender.fcgi? artid $=3633288 \&$ tool $=$ pmcentrez\&rendertype $=$ abstract $>$. https $: / /$ doi . org/10.4103/0976-9668.107317 